\title{
Interpersonal and Ideational Metaphors in the Writing of Thesis Texts of Undergraduate Students of English Study Program: A Systemic Functional Linguistic Approach
}

\author{
Magdalena Ngongo ${ }^{1 *}$ and Naniana Benu ${ }^{2}$ \\ $1 \& 2$ Artha Wacana Christian University Adi Sucipto Street, P.O. Box 147 Kupang, East Nusa \\ Tenggara Province, Indonesia
}

1*e-mail: magdalenangongo12@gmail.com, ${ }^{2}$ nanibenu@ukaw.ac.id

\begin{tabular}{|c|c|}
\hline Received: $27 / 08 / 2020$ & Published: $29 / 10 / 2020$ \\
\hline \multicolumn{2}{|c|}{ How to cite (in APA style): } \\
\hline $\begin{array}{l}\text { Ngongo, M., Benu, N. (20 } \\
\text { Students of Englis } \\
6(2), 113-120 . \text { doi: }\end{array}$ & $\begin{array}{l}\text { and Ideational Metaphors in the Writing of Thesis Texts of Undergraduate } \\
\text { A Systemic Functional Linguistic Approach. Retorika: Jurnal Ilmu Bahasa, } \\
.22225 / \text { jr.6.2.2320.113-120 }\end{array}$ \\
\hline
\end{tabular}

\begin{abstract}
This study describes how interpersonal and ideational metaphors were realised in th writing of theses texts written by undergraduate students of English study program. This study is a documentary analysis of descriptive method. Data in the form of corpus data were randomly taken from 15 theses among 70 theses in population. Data were analyzed by focusing on the semantic functions covering interpersonal and ideational metaphors. The results showed that interpersonal metaphor was realised in mood system and modality. Mood system was realised mostly in declarative clauses than interrogative and imperative ones. This fact was caused by the channel of text, written text. Modality was least used in the texts. Ideational metaphor was sin transitivity system in which material process was mostly applied than mental, behaviour, existential, relational and verbal processes. Nominalisation was selected as the mostly used property of linguistic feature in writing theses. Ideational metaphor was more used than interpersonal metaphor. This fact happens due to the text channel, written text. Therefore, it is suggested that lecturers in their teaching should consider their teaching by including metaphorical meaning, especially ideational and interpersonal metaphors. Besides, it is suggested to conduct research by comparing languages, national or international languages such as between Indonesian and English or else.
\end{abstract}

Keywords: Interpersonal Metaphor; Ideational Metaphor; Written Text; Undergraduate Students

\section{INTRODUCTION}

It is realised that as human being, people have to interact to other people in their life, and in doing so they use language as a main tool. Language used sometimes can be directly understood but sometimes requires interpretation in listeners or readers in order to get their meaning clearer. This fact generally happens because a speaker or a writer uses language variation to express his/her meaning. The use of this language variation to express meaning is known as metaphor (Halliday, 1994 :431). Language can be expressed in a congruent way, and the non-congruent way of encoding language is referred to as grammatical metaphor (Halliday, 1994, 1998; Halliday \& Matthiessen, 1999; Matthiessen, 1995).

Metaphor is not only understood from its linguistic phenomenon but also it involves cognitive competence since this phenomenon covers human's process of thought completely to catch a meaning behind a word, phrase or 
sentence being listened or read in a certain text or situation. Lakoff \& Johnson (1980) claimed metaphor as an understanding and experience of something through something else. Therefore, a person will understand new thing through other things that have been known before. Moreover, Lakoff and Johson said that experience of someone had culturalistic aspect; culture can serve for background of every human beings' experience. Thus, it can be said that comprehension of metaphor either spoken or written requires someone to use prior knowledge to understand meaning behind a word, phrase or clause that has metaphor.

Halliday (1994:341-342) proposed theory of functional grammar in which grammatical metaphor is introduced and described by a reason that metaphor can occur at different level, such as at lexical level and also at syntactical level. Halliday's view of grammatical metaphor is that language as a system of meaning potential and rules is not more than system of choice. It means that a speaker or a writer can choose special form of language to express himself/herself based on his/her purposes, and different meaning is realized by different forms of language too. Moreover, it was stated that whenever language is used there are two choices, namely choice of form that is consistent to a fact or congruent and choice of non-congruent fact. Choices that are not consistent to a fact according to Halliday is called metaphor. The use of language that is not congruent belongs to metaphor (Halliday, 1985b; Halliday, 1994b; Halliday, 1998; and Halliday \& Matthiessen, 2004).

Grammatical metaphor is different from lexical metaphor in the case that lexical meaning does not change except the change in its function. Halliday classified grammatical metaphor into two types, ideational metaphor and interpersonal metaphor. Ideational metaphor realized by transitivity covers the use of process and nominalization, while interpersonal metaphor relates to mood perspective and modality (Halliday, 1994b; Halliday, 1998; and Halliday \& Matthiessen, 2004). The example of grammatical metaphor (Ngongo, 2016) is such as the use of verb to noun 'we bring animals' (a clause) $\rightarrow$ 'animals brought by us' (phrase). This example indicates process of using clause to noun phrase. In lexical metaphor, it is the lexical meaning changed and not the use of word literally (Taverniers \& Ravelli, 2003; Taverniers, 2006).

The systematical use of either interpersonal or ideational metaphor is influenced by the context, so it can be said that a text both spoken and written text is influenced by context in which it is used. Therefore, it is essential and interesting to analyze whether the grammatical metaphor uses a 'text' or 'context'. Analyzing text means analyzing its language Brown \& Yule (1983:1) It is also stated by Halliday (1985a:10) that a linguist describing language without considering text is barren, and describing text without relating it to language is empty. Based on those views, the researcher thinks that it is essential and important to analyze a text since a text consists of language that is influenced by its context.

The aim of this study is to find out and describe the realization of interpersonal and ideational metaphors in theses texts written by undergraduate students of English study program. While the significant of this study covered theoritical and practical beneficial. Theoritically, it could support Systemic Functional Linguistics Theory proposed by Halliday Halliday, (1985, 1994, 2004, 2014). Practically, it gave contributions to either students, lecturers or other researchers in order to enrich or empower knowledge, skill or performance relating to the realization of interpersonal and ideational metaphor in either written or spoken texts.

Theory of Systemic Functional Linguistics is employed to find out and describe interpersonal and ideational metaphors in texts. It has developed from the work of Halliday (1985, 1994, 2004, 2014). The SFL conception of language is a set of resources that enable speakers to exchange meanings. The relation between social context and language is conceived as 'realizsation', that is, social contexts are realized by language. This theory concerns to the function as a fundamental property of language Halliday, (1985: 17). Language enables human beings to build a mental pictures of reality, to make sense of what goes on around them and inside them (Halliday, 1994: 106). In other words, this theory describes how language functions in use and it uses text as its approach to analyze language.

Metaphor based on Functional grammar is beyond the clause and it is known as metaphorical mode of expression. This metaphorical modes of 
expression according to (Matthiessen, 1995; Halliday \& Matthiessen, 2004; Halliday \& Matthiessen, 2014b) are characteristics of all adult discourse. Moreover, Halliday (1995) stated that young children speech ... lack grammatical metaphor. Based on this Halliday's statement the writer thinks that only adults always use metaphor either written or spoken texts. Therefore, in order to prove this statement the writer analyzed theses writing texts of undergraduate students focussing on interpersonal and ideational metaphors.

There are a number of previous researches conducted on metaphors, such as the research conducted by (Halliday, 1995) finding that normally in children's speech and in traditional children's rhymes and songs it seemed that children lack grammatical metaphors. Such a finding confirms that only adults usually use and understand metaphors in either written or spoken texts. However, this should be proven back and for that purpose the present study is conducted to examine the interpersonal and ideational metaphors in theses texts written by adults, who are under graduate students. Ngongo (2015) found out that in spoken texts adults used more ideational metaphor than interpersonal metaphor. Some researchers conducting researches on metaphor include Lakoff \& Johnson (1980), Eggins (1994), Halliday (1985b), Halliday (1994b), Halliday \& Matthiessen (2004), Taverniers \& Ravelli (2003), Taverniers (2006), Seyedvalilu \& Ghafoori (2016), Ngongo (2015), dan Kaneso (2016). These researches did not focus on discussion of metaphors in academic texts. Hence, the current study covers not only the interpersonal or ideational metaphor but also both interpersonal and ideational metaphor with an addition of modality metaphor which includes in interpersonal metaphor. Interpersonal metaphor is realized in metaphor of mood and modality; and ideational metaphor is realized in metaphor of transitivity.

\section{METHOD}

A phenomenology approach-based qualitative method is the method applied in this study. A library research was conducted at which thesis texts were studied. The type of data used in this study is qualitative data. It was also supported by quantitative data in order to give more explanation of the qualitative analysis. The data was collected by directly garthering the English theses written by undergraduate students who graduated in September 2018. The total number of thesis was 70. By applying purposive random sampling technique, there were 15 students' English thesis taken to be analyzed. There were five chapters in each thesis. All of of the theses discuss about English teaching and learning. Data were analyzed by applying descriptive qualitative analysis method, especially matching method proposed by Mahsun (2007). Data were analyzed by focusing on Systemic Functional Linguistics (SFL) theory especially on the semantic domain. The activity of analying the data include reserachers: (1) and clasified the data into that consisting of metaphors, interpersonal and ideational metaphors, (2) analyzed the metaphors used in the texts and (3) interpreted and reported the results. Based on matching technique, data were analyzed by specifying to the analysis of grammatical metaphor, covering ideational and interpersonal metaphors. The frequency of metaphors in the texts was accumulated in order to give more explanation about the realization of them in the texts. The results of the study were presented either in tables or words, which were then described or narrated in words, sentences and paragraphs.

\section{RESULTS AND DISCUSSION}

Based on the analysis it was found that the writing of the these texts of the undergraduate students includes ideational and interpersonal metaphors. Data of ideational and interpersonal metaphors in texts are presented in Table 1.

Table 1.

Frequency of Ideational and Interpersonal Realization in Each Thesis Text

\begin{tabular}{|l|c|c|c|c|c|c|c|c|c|c|c|c|c|c|c|l|}
\hline M/TT & T1 & T2 & T3 & T 4 & T5 & T6 & T7 & T8 & T9 & T10 & T11 & T12 & T13 & T14 & T15 & Total \\
\hline Id.M & 65 & 22 & 69 & 75 & 65 & 65 & 56 & 53 & 71 & 63 & 59 & 65 & 73 & 52 & 77 & 930 \\
\hline It.M & 20 & 108 & 45 & 46 & 37 & 41 & 13 & 18 & 58 & 24 & 13 & 68 & 25 & 23 & 26 & 565 \\
\hline Total & 85 & 128 & 114 & 121 & 102 & 106 & 69 & 71 & 129 & 87 & 72 & 133 & 98 & 75 & 103 & 1495 \\
\hline
\end{tabular}

\section{Notes:}


M : Metaphor

TT : Thesis Text

Id.M : Ideational Metaphor

Id.M : Interpersonal Metaphor

Table 1 pictures the use number of both ideational and interpersonal metaphors in the writing of undergraduate students' thesis texts that consisted of 1495 times. The table indicates that the frequency of ideational metaphor realization is higher (930 times) than that of interpersonal metaphor (565 times). Implicitly, it reveals that the undergraduate students more expressed their experience using nominalization rather than experience exchange. This is also because of the channel of text, namely written texts. This fact relates to Ezeifeka's (2015: 7) research finding that "nominalization in research abstracts writing presents the evidence of high literacy..." More explanation of interpersonal and ideational metaphor in text is orderly presented as follows.

\subsection{Realization of Interpersonal Metaphor in Texts}

Realizaton of interpersonal metaphor in the thesis text can be seen in the use of mood and modality. Relating to table one it can be seen that the total frequency of the use of interpersonal metaphor is 565 times within the texts taken from 15 theses. Interpersonal metaphor can be in the realization of propostion and proposal in which

proposal is projected in projection nexus and proposition is projected in projection nexus (Halliday \& Matthiessen 2014 :701). Both of them can be realized in declarative and interrogative clauses-mood system.

The following constructions indicate how interpersonal metaphors are realized.

(1) It cannot be denied that writing is not a simple task (TW 9:1).

(2) He also found out that peer feedback encouraged critical reasoning (TW 9:5).

(3) The students were asked how to give advice to friend.... (TW10:34).

Note: TW refers to Thesis Writing

Construction (1) showed the use of modality and construction (2) and (3) indicate declarative clause mood. All of them were upgraded or made into projection clauses. Based on the data gathered, there were no interrogative, exclamative and imperative-mood clauses. This happened due to the channel of the text, which is written text. The frequency of the realization of interpersonal metaphor in mood and modality can be seen in Table 2 .

Table 2.

Frequency of Interpersonal Metaphor Realization in Each Thesis Chapter

\begin{tabular}{|c|c|c|c|c|c|c|}
\hline \multirow{2}{*}{ Thesis } & \multicolumn{5}{|c|}{ Chapter } & \multirow{2}{*}{ Total } \\
\cline { 2 - 6 } & I & II & III & IV & V & \\
\hline 1 & 7 & 10 & 0 & 2 & 1 & 20 \\
\hline 2 & 3 & 16 & 3 & 77 & 12 & 108 \\
\hline 3 & 2 & 22 & 3 & 16 & 2 & 45 \\
\hline 4 & 5 & 21 & 1 & 14 & 5 & 46 \\
\hline 5 & 5 & 10 & 2 & 18 & 2 & 37 \\
\hline 6 & 4 & 15 & 6 & 14 & 2 & 41 \\
\hline 7 & 2 & 5 & 0 & 6 & 0 & 13 \\
\hline 8 & 3 & 11 & 0 & 2 & 1 & 18 \\
\hline 9 & 9 & 39 & 1 & 6 & 2 & 58 \\
\hline 10 & 2 & 11 & 1 & 9 & 1 & 24 \\
\hline 11 & 0 & 7 & 1 & 5 & 0 & 13 \\
\hline 12 & 4 & 24 & 1 & 38 & 1 & 68 \\
\hline 13 & 6 & 7 & 1 & 14 & 1 & 25 \\
\hline 14 & 2 & 15 & 0 & 3 & 3 & 23 \\
\hline 15 & 2 & 14 & 1 & 8 & 1 & 26 \\
\hline Total & 56 & 227 & 21 & 232 & 34 & 570 \\
\hline
\end{tabular}

Table 2 shows the frequency number of interpersonal metaphor in each chapter of the thesis. As shown in the table, the total frequency of the interpersonal metaphor realization in all 
chapter is 570 times. There were several chapters at which interpersonal metaphor is not realized in their in texts, such as Chapter III of text number $1,7,8$ and 14 and Chapter $\mathrm{V}$ of thesis number 7 and 11. This is due to the channel of the text that is written text. It also can be because of the students' capability of using variety of moods especially the declarative clause. Interpersonal metaphors were more used in Chapter IV, followed by chapter II, I,V and III. Generally Chapter III and V showed the leat used of metaphors in texts. Chapter IV the part where metaphors were mostly used since in this chapter students explained, described fact by reporting facts using projection nexus. The, the chapter at which metaphors were least used is Chapter III. It is because the students mentioned only methodological information using simple clauses without projection. Besides, the Table 2 also pictured that there was a case in which the total number use of interpersonal metaphor as in text two was highest than others. This fact caused by repetition of information stated in Chapter IV in which the information described showing that it was declarative of mood system applied such as One student said that she used writing skill..... Four students said that they ...etc. Other examples of interpersonal metaphors realizaton in mood and modality in texts are presented in Table 3.

Table 3.

Interpersonal Metaphor Realization in Mood and Modality in the Texts of Each Thesis

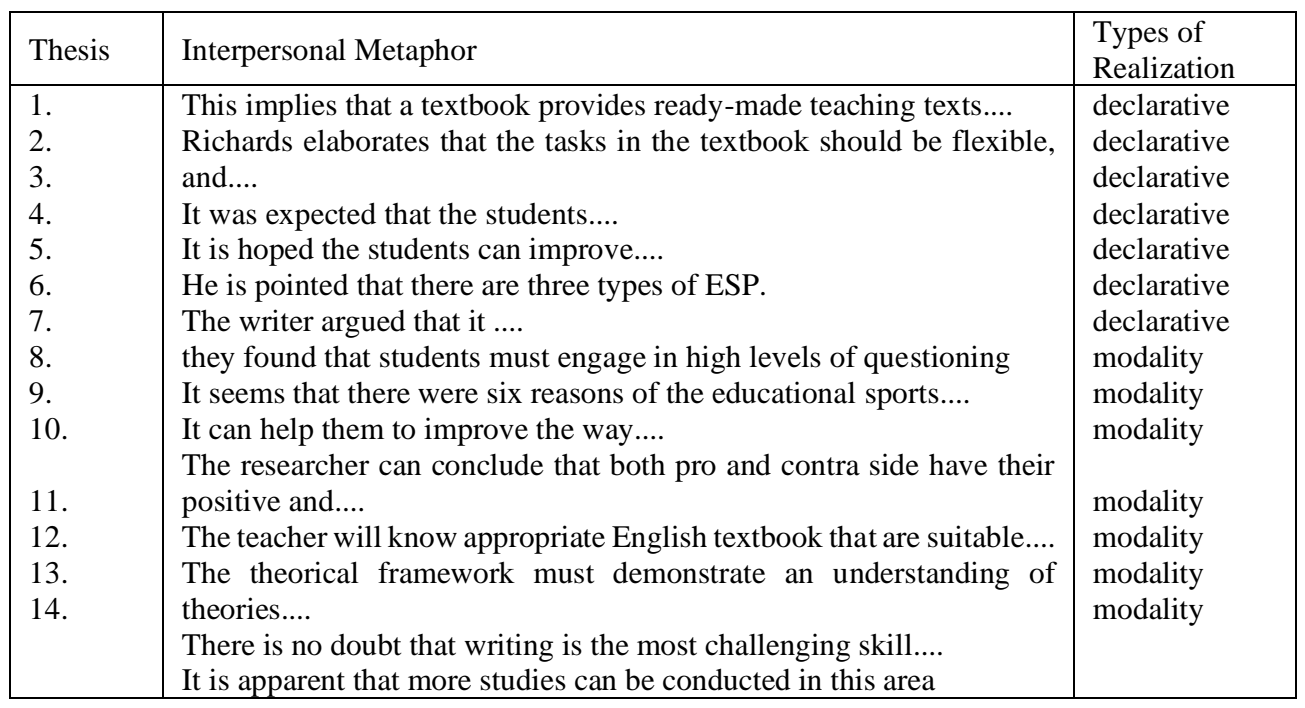

Shown in Table 3 it can be seen the examples of interpersonal metaphors in text which are only realized in declarative clauses and modality. There were no command, interrogative and exclative causes since these kinds of clauses are usually used in a dialogue. According to Halliday \& Matthiessen (2004) the potential negotiation in a dialogue created by metaphor of mood was directly related to contextual variables of tenor. Based on this view, this fact proved that in written texts interrogative, imperative and exclamative clauses might be limited used or almost was not used in texts except declative clauses. Modality in texts were also used even though they were limited in use. Modality system showing interpersonal metaphor was that of probability, usuality and obligation or inclination. This fact proved the view of Halliday \& Matthiessen (2004) stating that with modality, it is very clear that certain grammatical environments constitute metaphorical realisations of modality. Lau (2009) found out that in Chinese Hong Lou Meng there were various ways of realizing the interpersonal function with mood system such as modal particles, terms of address, stereotyped structures, and it was stated that all these devices helped the realization of interpersonal function through mood metaphor. The use of various types of modality in this texts has proved the statement of (To \& Thomas, 2017) who found out that the various types of interpersonal metaphor of modality were used to persuade readers.

\subsection{Realization of Ideational Metaphor in the Thesis Texts}

Based on the view of Halliday \& Matthiessen (2014b), metaphor is incongruent realizational relation between semantic and 
lexicogrammar. Moreover, they said that the general tendency for ideational metaphor is to 'downgrade' the domain of grammatical realization of a semantic sequence, figure or element (Halliday \& Matthiessen, 2014b). Ideational metaphor usually used in the writing of thesis texts. Data showing the use of idealization metaphor are as follows.

(4) S/he already had the requested information.... (TW10:36)

(5) The writer categories the mark based on kinds of positive punishments. (TW 11:5)

(6) The teacher will give the punishments additional assignment (TW11:9).

The three clauses number (4)-(6) indicate the realization of ideational metaphors. Clause (4) and (6) evidence nominalization use, whereas clause (5) indicates the use of prepositional phrase. Both clauses in this construction were downgraded clause. The frequency of ideational metaphor use in each chapter is shown in Table 4.

Table 4.

The Use Number of Ideational Metaphors in Chapters of Texts.

\begin{tabular}{|l|l|l|l|l|l|l|}
\hline \multirow{2}{*}{ Thesis } & \multicolumn{5}{|l}{ Chapter of Thesis and Frequency of } & \multirow{2}{*}{ Total } \\
\cline { 2 - 6 } & Metaphor Use & I & III & IV & V & \\
\hline 1 & 9 & 32 & 2 & 17 & 5 & 65 \\
\hline 2 & 3 & 13 & 2 & 3 & 1 & 22 \\
\hline 3 & 8 & 20 & 12 & 17 & 12 & 69 \\
\hline 4 & 12 & 25 & 4 & 24 & 10 & 75 \\
\hline 5 & 17 & 35 & 4 & 4 & 5 & 65 \\
\hline 6 & 10 & 32 & 5 & 13 & 5 & 65 \\
\hline 7 & 6 & 14 & 6 & 22 & 8 & 56 \\
\hline 8 & 7 & 22 & 6 & 14 & 3 & 53 \\
\hline 9 & 10 & 43 & 3 & 10 & 5 & 71 \\
\hline 10 & 12 & 23 & 4 & 18 & 6 & 63 \\
\hline 11 & 12 & 21 & 7 & 12 & 7 & 59 \\
\hline 12 & 8 & 19 & 6 & 25 & 7 & 65 \\
\hline 13 & 10 & 18 & 5 & 30 & 10 & 73 \\
\hline 14 & 15 & 20 & 4 & 7 & 6 & 52 \\
\hline 15 & 10 & 20 & 8 & 22 & 17 & 67 \\
\hline Total & 149 & 357 & 78 & 238 & 106 & 920 \\
\hline
\end{tabular}

Table 4 pictured the frequency of ideational metaphor realization. As shown in the table the metaphor was realized 920 times. The table also informs that the Chapter at which the ideational metaphor was mostly realized is Chapter II, followed by chapter four, one and five. This fact caused by way of summarizing and paraphrasing other writers' views using nominalization. They compressed clauses in oder to make meaning clearer and more informative. In other words, the students downgraded clauses using nominalization to make message more understandable. This findings supports to the view of Halliday \& Matthiessen (2014b) which stated that nominalizing was the single most powerful resources for creating gramatical metaphor. Data of ideational metaphor can be seen in table five. Moreover, Halliday stated that by this device, processes are rewoeded metaphorically as nouns and function as thing in the nominal group. Data of showing the use of ideational metaphors are presented in Table 4.

Table 5.

Ideational Metaphor Examples in the Texts of the Theses

\begin{tabular}{|l|l|l|l|}
\hline Thesis & Metaphorical Wording & Proses Type & Downgrading \\
\hline 1 & ... the students in manipulating words...., & material & prep.phrase \\
\hline 2 & Writing task can make students...., & material & nominal group \\
\hline 3 & ... spontaneous communication of meaning & verbal & nominal group \\
\hline 4 & ...in mastering the material. & mental & prep.phrase \\
\hline 5 & Realizing the factor affecting the teaching.... & mental & nominal group \\
\hline 6 & Students do not ask for a celebration on the grounds & behaviour & nominal group \\
\hline 7 & $\begin{array}{l}\text { The tenth question and answer relationship is the } \\
\text { students asks some questions }\end{array}$ & relational & nominal group \\
\hline
\end{tabular}




\begin{tabular}{|l|l|l|l|}
\hline 8 & $\begin{array}{l}\text { the teacher tell the students the expectations in teaching } \\
\text { learning process. }\end{array}$ & mental & nominal group \\
\hline 9 & The movement of the teacher shows that... & behaviour & nominal group \\
\hline 10 & The teacher will monitor about their pronunciations & verbal & prep.phrase \\
\hline
\end{tabular}

Referring to table five it can seen there some examples of ideational metaphors. The ideational metaphors realized in process type such as material, mental, behaviour, relational and existential processes. Downgrading were in nominalization and paraprasing. The use of nominalization can reduce the number of clauses used in text, and information stated in text could be more compressed. The downgrading in texts can be started with a whole sequence of figures with a single figure or with a single element within a figure (Halliday \& Matthiessen, 2014: 719). The ratio of grammatical metaphors, especially ideational metaphor found in the textbooks according to (Kaneso, 2016) was an example of EFL textbook features of grammatical metaphors.

\section{CONCLUSION}

Referring to explanation presented in the previous parts, it can be concluded that (1) interpersonal and ideational metaphors were both used in texts. Interpersonal metaphors were realized in mood system and modality whereas ideational metaphors were realized in transitivity system. (2) the realization of interpersonal metaphors in mood system in texts was dominated in declarative mood. Realization of modality was in probability, usuality and obligation or inclination. The use of modality was least used than declarative of mood. This might be because by the limited knowledge of the students of how to upgrade clauses. The use of modality in text proves what Halliday \& Matthiessen (2004) meant that with modality, it was very clear that certain grammatical environments constituted metaphorical realizations of modality. (3) Realization of ideational metaphor were most used than interpersonal metaphor because of the text channel, written text. Nominalization was the typical ideational metaphor and it is to 'downgrade' the domain of grammatical realization of a semantic sequence, figure or element (Halliday \& Matthiessen, 2014b). It can be claimed that nominalization was selected as the most property of linguistic feature in writing theses or other scientific texts. In this case the use of material process was dominated than other process types in transitivity system. Prepositional phrases also pictures the ideational metaphor realization. Thus, it is suggested that lecturers should give more exercises on how to use interpersonal and ideational metaphors especially on how to upgrade and downgrade clauses since understanding semantic through metaphor is important in comprehending the messages within texts. What metaphorical interpretation does is to suggest how an instance in the text may be referred to the system of the language as a whole (Halliday \& Matthiessen, 2004). This view suggested the importance of interpreting text from the gramatical metaphsor (interpersonal and ideational) point of view. It is also suggested to study more about metaphor in other scientific or academic writing or formal spoken texts.

\section{REFERENCES}

Brown.G, \& Yule, G. (1983). Discourse Analysis. Cambridge University Press.

Eggins, S. (1994). An Introduction to Systemic Functional Linguistics. Pinter Publishers.

Ezeifeka R., C. (2015). Grammatical Metaphor: In Search of Proficency in Research Abstract Writing. Sage Jurnal.

Halliday, M. A. K. (1985a). An Introduction to Functional Grammar. Edward Arnold.

Halliday, M. A. K. (1994a). An Introduction to Functional Grammar (2nd ed.). Edward Arnold.

Halliday, M. A. K, \& Matthiessen, C. (2014a). An Introduction to Functional Grammar (3rd ed.). Hodder Arnold.

Halliday, M. A. K. (1985b). An Introduction to Functional Grammar. Edward Arnold.

Halliday, M. A. K. (1994b). An Introduction to Functional Grammar. Edward Arnold.

Halliday, M. A. K. (1998). Things and Relations: Regrammaticising experience as technical knowledge. In Reading Science: Critical and Functional Perspectives on Discourses of Sciences.

Halliday, M. A. K. (1995). On Language in Relation to the Evolution of Human Consciousness. Of Thoughts and Words (Proceedings of Nobel Symposium 92: The Relation between Language and Mind), 45-84.

Halliday, M. A. K., \& Matthiessen, C. M. I. M. 
(1999). Construing Experience Through Meaning: A Language-based Approach to Cognition (OpenLlinguisticsSseries). Continuum.

Halliday, M. A. K., \& Matthiessen, C. M. I. M. (2004). An Introduction to Functional Grammar (3rd ed.). Hodder Arnold.

Halliday, M. A. K., \& Matthiessen, C. M. I. M. (2014b). Halliday's Introduction to Functional Grammar. Routledge.

Kaneso, Y. (2016). Ideational Grammatical Metaphorical Features of EFL Textbooks [Marshall University].

Lakoff, G., \& Johnson, M. (1980). Metaphors We Live By (1st ed.). University of Chicago Press.

Lau, Y. L. (2009). Kajian Metafora Kata Nama dan Kata Sifat dalam Cerpen Bahasa Mandarin [Universiti Malaya].

Mahsun. (2007). Metode Penelitian Bahasa. PT Raja Grafindo Persada.

Matthiessen, C. M. I. M. (1995). Lexicogrammatical Cartography: English SystemsInternational. Language Sciences Publisher.

Ngongo, M. (2016). Systemic Analysis of Text Appraisal on Students' Thesis writing in English. Journal of Scientific Research and Studies, 7(4), 67-72.

Ngongo, M. (2015). Analisis Sistemik Metafora Gramatika dalam Teks Bahasa Waijewa. In I. A. M. Puspani \& Dkk. (Eds.), Strategi Pemberdayaan Bahasa Lokal demi Pelestarian Budaya Bangsa dan Upaya Penguatan Jati Diri (pp. 633-642). Udayana University Press.

Seyedvalilu, S., \& Ghafoori, N. (2016). Ideational Grammatical Metaphor in Merry Shelly's Frankenstein and its Cinematic Adaptation. The Journal of Applied Linguistics, 9(19), 141160.

Taverniers, M., \& Ravelli, L. J. (2003). Grammatical Metaphor in SFL: A Historiography of the Introduction and Initial Study of the Concept. In A.-M. Simon-Vandenbergen \& L. J. Ravelli (Eds.), Grammatical Metaphor: Views from Systemic Functional Linguistics (1st ed., pp. 533). John Benjamins Publishing Company.

To, V., \& Thomas, D. (2017). Examining Interpersonal Metaphor of Modality in Successful Primary Persuasive Texts. In P. Chappell \& J. S. Knox (Eds.), Transforming texts: Proceedings of the 44th International Systemic Functional Linguistics Congress (pp. 1-6). The Organising Committee of the 44th International Systemic Functional Congres.

\section{Appendix: Title of Undergraduate Student's Theses}

1. An Analysis on Writing Task on English Focus An English Textbook for the Eight Grade Junior High School Thesis Writing 1
2. English Need Analysis of Educational Sports Students at the Second Grade of Artha Wacana Christian Thesis Writing 2 University in Academic Year 2017/2018

3. An Analysis of Speaking Skill in Debating Competition at Artha Wacana Christian University Thesis Writing 3 Based on Pro's and Con's Point of view of British Paliamentary System

4. Teacher's Feedback For Students Writing Skill Improvement In SMP Reformasi Plus Noelbaki Thesis Writing 4 In Academic Year 2017/2018"

5. A Descriptive Study on Classroom Management Applied by English Teachers at SMP N 1 Thesis Writing 5 Amanatun Selatan

6. A Sudy on Non-standard English in the Responsive Speaking Class : A Case Study at the Second Semester Thesis Writing 6 Students of EESP at Artha wacana Christian University

7. A descriptive study on Language Allocation by English Lecturer of English Education Study program in Thesis Writting 7 Bilingual Subject at Artha Wacana Christian University in academic year 2017/2018

8. A Descriptive Study on Question and Answer Relationship ( QAR ) in Teaching Reading at English Thesis Writing 8 Education Study Program of AWCU in Academic Year 2017/2018

9. Online Proofreading Tools for Self-Correcting Responsive Writing Texts : Autonomous Learning for Thesis Writing 9 Artha Wacana Christian University Students

10. Conversation Analysis of Repair Initiations in The Classroom Interaction Between The English Teacher Thesis Writing 10 and The Eight Grade Students of SMP 4 Kota Kupang in The Academic Year 2017/2018

11. An Analysis on the Implementation Rewards and Punishments Strategy by English teachers at Junior high Thesis Writing 11 schools at Kupang Tengah in school year 2017/2018

12. Classroom Interaction in English Teaching Learning at the Second grade of SMPN 1 Kupang 2018/2019 Thesis Writing 12 school year

13. A descriptive study on classroom management applied by English students of UKAW in the internship Thesis Writing 13 program at SMP Negeri 16 Kupang city in academic year 2017/2018 Analysis on Paratones used by teacher in teaching Drama course a case study at Artha Wacana Christian Thesis Writing 14 University Kupang Academic year 2018".

14. An Analysis on EFL Interaction Patterns for Speaking Activities at SMPN Bakalang East Pantar in Thesis Writing 15 Academic Years2018/ 2019 
